\title{
Worker Churning and Firms' Wage Policies
}

\author{
Pedro S. Martins* \\ Queen Mary, University of London; \\ IZA, Bonn; and CEG-IST, Lisbon
}

This version: 28 February 2007

\begin{abstract}
If a random firm were to increase its wages, would that decrease the firm's churning ("excessive" worker reallocation)? Although the trade-off between wage and churning costs has received attention in both the labour and human resource management literatures, there seems to be no evidence about the causal impact of wages upon churning. This paper seeks to fill that gap by considering detailed Portuguese matched employer-employee panel data and different identification methods. After presenting comprehensive evidence about job and worker flows and churning, we find that even models based on within-firm time differences do still generate the negative association between wages and turnover found in most research. However, that result no longer holds when we consider instrumental variables based on minimum wages determined by collective bargaining arrangements. One possible interpretation of our finding is that workers' effort may not be sufficiently sensitive to wages: employers may replace workers priced out of the labour market with more skilled individuals, so that churning does not fall.
\end{abstract}

Keywords: Worker Turnover, Endogeneity, Personnel Economics, Efficiency Wages.

JEL codes: J31, J50, J63, M50.

\footnotetext{
${ }^{*}$ I thank, without implicating, Harald Dale-Olsen, Pedro Portugal, the editors (Ana Rute Cardoso and Chiara Monfardini) and a referee for their very useful comments and Banco de Portugal for logistical assistance. Address: School of Business and Management, Queen Mary, University of London, Mile End Road, London E1 4NS, United Kingdom. Email: p.martins@qmul.ac.uk. Web: www.qmul.ac.uk/ bsw019. Phone: 0044/0 2078827472.
} 


\section{Introduction}

One of the several striking stylised facts that has emerged from the literature on job flows (Davis et al, 1996) is the large extent of worker churning (the excess of worker reallocation with respect to job reallocation). Contrary to what one may expect, even firms that exhibit stable levels of employment typically display high levels of hires and separations. Moreover, firms that are increasing the size of their workforce can exhibit a considerable number of separations, while hirings also tend to coexist with separations in firms that are cutting employment.

For instance, in a well-known study, Burgess et al (2000) document substantial levels of worker churning, at $12.1 \%$ in manufacturing and $22.8 \%$ in non-manufacturing. These churning levels represent, respectively, $61.9 \%$ and $70.4 \%$ of total worker flows, implying that most hirings and separations that occur within firms do not translate into changes in firm size (Hamermesh et al., 1996, Albaek and Sorensen, 1998, Abowd et al., 1999, Burgess et al., 2001, and Ilmakunnas and Maliranta, 2005, present additional evidence of churning). ${ }^{1}$

The importance of churning in most firms' employment policies raises important questions about the quality of the matching between employers and employees that is achieved by the labour market. For instance, since hirings or separations entail costs for both employers and employees, and low average tenure levels are typically detrimental to the acquisition of productivity-enhancing firm-specific skills, one may expect that the market would adjust in such a way that churning would not be such an important phenomenon. For instance, as firms age and gain experience, they would presumably be able to improve their hiring and retention practices, in order to minimise churning.

In any case, it is important to acknowledge the role of wages upon the amount of churning present in the labour market. For instance, one of the mechanisms that may generate efficiency wages (Akerlof and Yellen, 1986) involves the reduction in turnover costs achieved by increasing pay. However, little is known in both the labour economics and the human resource management literatures about the specific trade-offs between wage and churning costs faced by firms. More specifically, there is apparently no evidence about whether a random firm that were to increase its wages would typically achieve a reduction in churning. Indeed, while there is plenty of evidence about the association between different HRM variables and different firm performance indicators, there is a disappointing lack of evidence about causal relationships (Guest et al, 2003; some exceptions include Lazear, 1995, and Bandiera et al., 2005).

This paper seeks to fill a part of such large gap in our understanding of the causal impact of personnel policies by focusing specifically on the relationship between churning and pay (see also Barth and Dale-Olsen, 1999, and Dale-Olsen, 2006). Our analysis is implemented by considering long and detailed Portuguese matched employer-employee panel data and different identification methods, including instrumental variables. After describing evidence about job and worker flows and churning for the entire economy (including the services sector, unlike many related papers), we present regression results that explain the role of wages upon the variability of churning levels across and within firms over time.

As in other studies, we find, at first, that churning is negatively related to wages. This result still holds when considering only within-firm time variation. However, because the wages paid by firms are, at least to some extent, a choice variable, such estimates cannot necessarily be interpreted as causal parameters. Once we try to tackle such non-randomness, we obtain our main result: by

\footnotetext{
${ }^{1}$ See also Martins (2006b) for evidence that churning does not only correspond to "replacement hiring", the most common interpretation in the literature: events involving "job upgrading" or "job downgrading" (i.e. firms changing the profile of their workforces in terms of skills and/or occupations) also explain part of the "excessive" worker turnover (with respect to job flows).
} 
instrumenting wages using variation in wages driven by collective bargaining contracts, we find that the relationship between wages and churning is actually non-negative: either significantly or insignificantly positive, depending on the estimates.

The remaining of the paper is as follows: Section 2 presents the data and some statistics about job and worker flows. Section 3 describes the results, based on different estimation methods and samples. Finally, Section 4 offers a short summary.

\section{Data and Descriptive Statistics}

We employ the "Quadros de Pessoal" (Personnel Records) data set, an annual census of all firms based in Portugal that have at least one employee. The census, conducted by the Ministry of Employment, requires that each firm provides detailed information about itself (size, industry, region, age, sales, etc) and also about each one of its employees (gender, age, schooling, tenure, wages, etc). Moreover, each firm and each employee is assigned a unique identifier, allowing one to follow them over time. In this paper, we use data from all years from 1986 to 2000 (except 1990, when only firm-level data are available).

"Quadros de Pessoal" can thus be characterised as a matched employer-employee panel data set covering a very large share of the entire labour market over a relatively long period. (The groups of workers not covered are the unemployed, the civil servants, the self-employed and the informal workers.) The data used here includes information about 2.4 million firms-year and almost 30 million workers-year. Moreover, because the main goals of the census are to check compliance with employment law and to provide statistical evidence about the labour market, great care is devoted to data quality. ${ }^{2}$

All flow variables are defined in the way that has become standard in the literature, as described in Davis et al (1996). Each rate is constructed by dividing a given flow (job creation, for instance) by the average employment of the firm over the two periods analysed. For instance, the job creation rate is defined as $\mathrm{JC}=\frac{L_{t}-L_{t-1}}{0.5\left(L_{t}+L_{t-1}\right)}$, if $\mathrm{L}_{\mathrm{t}}>\mathrm{L}_{\mathrm{t}-1}$, or 0 , if $\mathrm{L}_{\mathrm{t}}<\mathrm{L}_{\mathrm{t}-1}$, in which $\mathrm{L}_{\mathrm{t}}$ stands for the firm size in period t. Similarly, the job destruction rate is defined as JD $=\frac{L_{t-1}-L_{t}}{0.5\left(L_{t}+L_{t-1}\right)}$ if $\mathrm{L}_{t}<\mathrm{L}_{\mathrm{t}-1}$, or 0 , if $\mathrm{L}_{\mathrm{t}}>\mathrm{L}_{\mathrm{t}-1}$, while the net job creation rate (NJCR) corresponds to JC - JD and the job reallocation rate $(\mathrm{JR})$ is $\mathrm{JC}+\mathrm{JD}$. The hiring rate is $\mathrm{H}=\frac{\text { Hirings }_{t, t-1}}{0.5\left(L_{t}+L_{t-1}\right)}$, in which Hiring $\mathrm{s}_{\mathrm{t}, \mathrm{t}-1}$ denotes the number of workers present in the firm in period t but not in period $\mathrm{t}-1$, while the separation rate is $\mathrm{S}=$ $\frac{\text { Separations }_{t, t-1}}{0.5\left(L_{t}+L_{t-1}\right)}$, in which Separations $\mathrm{s}_{\mathrm{t}, \mathrm{t}-1}$ denotes the number of workers present in the firm in period t-1 but not in period t. Finally, the worker reallocation rate (WR) is $\mathrm{H}+\mathrm{S}$, and the churning rate $(\mathrm{CR})$ is defined as $\mathrm{WR}-\mathrm{JR}$.

All descriptive statistics and regression results are carried out by weighting each firm-level observation by its average employment.

\footnotetext{
${ }^{2}$ Although we do believe data quality is indeed of high standards, there are inevitably some missing or incorrect observations, particularly for smaller firms and/or in the earlier years of the census, when computers were not so widespread.
} 
We follow Blanchard and Portugal (2001) (see also Varejão, 2003) in the computation of worker flows and classify as (new) hirings all workers whose date of hiring was subsequent to the census date of the previous period (March, up to 1993, and October, from 1994 onwards). Since $\Delta \mathrm{L} \equiv \mathrm{H}-$ $\mathrm{S}$, in which $\mathrm{L}$ is firm size, $\mathrm{H}$ is hirings and $\mathrm{S}$ separations, the number of separations can be defined as $\mathrm{H}-\Delta \mathrm{L}$, the difference between the total number of hirings in that firm-year and the change in firm size. ${ }^{3}$

Table 1 presents some descriptive statistics. Given that they refer to the entire population of Portuguese firms with at least one employee, they may deserve some particular attention. The first two columns refer to all firms in all years (a total of 2,899,846 firms-year, including interpolations ${ }^{4}$ ). The remaining four columns refer to 1987 and 2000 (given that 1986 is the first year in our data, it is not possible to compute job and worker flows variables for that year), which include, respectively, 128,754 and 301,607 firms.

Average firm size is 1,032 - in other words, given that our statistics are weighted by firm size, an average worker has 1,031 colleagues in her firm. 3\% of all firms-year are new firms, while 5\% are in their last year in the data. About $9 \%$ of firms are foreign owned (defined as when at least $50 \%$ of the equity of the firm is held by foreign investors). $39 \%$ of the workforce is female and their average schooling attainment is 6.7 years. They have 24 years of experience and almost 100 months of tenure, while their last promotion occurred, on average, 56 months before the date of the census.

Average job creation rate is $14 \%$, while job destruction rate is $12 \%$, resulting in a net job creation rate of $2 \%$. Hiring and separation rates are almost twice that, at $23 \%$ and $22 \%$. It is also noticeable all four rates increase significantly from 1987 to 2000, particularly the job destruction and the separation rates (from $9 \%$ to $18 \%$ and from $17 \%$ to $27 \%$, respectively).

Figure 1 presents the distribution of net job creation rates in 2000 (similar figures could be presented for the remaining years). As documented in other studies, we find a large concentration around zero, the modal category, and at the two spikes at -2 and 2 (firm deaths and births, respectively). Except for those two extreme cases, very few firms (almost none) exhibit changes in employment of less than (greater than) the smaller spikes at $-2 / 3(2 / 3)$.

Coming back to Table 1, one can calculate churning rates at an average of about $20 \%$, corresponding therefore to almost half of the worker reallocation rate. Moreover, we also find that the distribution of the churning rates is highly skewed. Out of the 2.3 million firms-year for which churning can be calculated, churning is greater than zero in only about $26 \%$ of the cases (not weighting by size). From Figure 2, which presents the distribution of churning rates in 2000, we can also see that only a very limited number of firms exhibit churning rates above $50 \%$.

Moreover, gross monthly pay is on average $€ 738$ (2004 prices), ranging from $€ 595$ in 1987 to $€ 814$ in 2000. Hourly pay also increases, at a slightly higher rate. The last row refers to the variable that will be used as an instrument later in the paper. The variable is the percentage of workers in each firm that earn a base wage that is the modal wage in the workers' occupation (defined at the fourdigit level). On average, about $18 \%$ of workers in each firm (again, weighted by firm size) earn those modal wages.

\footnotetext{
${ }^{3}$ One problem with this approach is that any underestimation of $\mathrm{H}$ (for instance, because of missing or incorrect hiring dates) will also lead to the underestimation of S. However, from a more detailed analysis of this issue - see Martins (2006a) -, we believe this problem is not particularly relevant in our study.

${ }^{4}$ A closer inspection of the data indicated that some firms do not report their information in some years. In order to avoid biases in terms of the artificial definition of too many new and closing firms, the firm size of those firm-years (less than $10 \%$ of the firms-year used) was interpolated.
} 
Table 2 presents more detailed results about the flows of jobs and workers across firms. In the first table, the firms are divided into their sector of activity (agriculture, manufacturing and services). ${ }^{5}$ As in other studies, the services sector exhibits much higher rates of job creation and destruction and of worker hirings and separations - and therefore the services sector also exhibits higher rates of job and worker reallocation. For instance, worker reallocation is $51.5 \%$ in services and only $39.2 \%$ in manufacturing. However, we find that the agriculture sector is characterised by even higher job and worker reallocation rates. Finally, another important result is that, while churning is much higher in services than in manufacturing, its share in total worker reallocation is very similar in the two sectors, at about $50 \%{ }^{6}$

\section{Results}

In this section we present the main results of the paper. These results involve the estimation of a simple reduced-form linear equation that relates the churning rate of a firm in a given year with the average wage paid by that firm to its workers plus a number of controls. These controls include different measures of firm heterogeneity that may help explaining churning rates, including firm and time fixed effects. The equation is as follows:

$$
C_{i t}=\beta W_{i t}+X_{i t}{ }^{\prime} \delta+\gamma_{i}+\delta_{t}+\varepsilon_{i t}
$$

$\mathrm{C}_{\mathrm{it}}$ is the churning rate of firm $\mathrm{i}$ in period $\mathrm{t}, \mathrm{W}_{\mathrm{it}}$ is the average wage, and $\mathrm{X}_{\mathrm{it}}$ are firm-year characteristics (the percentage of women in the workforce, average education and average experience of the workers, the levels of sales and of equity and $\log$ firm size), $\gamma$ and $\delta$ are firm and time fixed effects, respectively. As suggested above, the firm fixed effects are of particular importance, as otherwise one would have to assume that the wage policy of the firm is chosen randomly in order to interpret the $\beta$ coefficient as the causal impact of wages upon churning.

The estimation method also deserves some discussion. Given the large number of zeros in the dependent variable, a tobit model would be appropriate. However, to the best of our knowledge, an estimator for this model with fixed effects has not yet been developed. We are also not aware of tobit models, even with random effects, that could incorporate instrumental variables.

Due to those technical constraints, our first approach is to employ a random effects tobit model. We then adopt a standard OLS model, first excluding firm fixed effects, and then including them. Finally, given that we are also concerned about the endogeneity of the within-firm time variation of wages, we also consider a model in which we instrument the change in wages. As a robustness test, we also replicate the previous models considering only firms that have a positive level of churning, including with a specification based on log churning and log wages.

Our instrument is the share of workers being paid collective bargaining contractual wages (henceforth SWCW). The choice of this variable is motivated by the very interesting work by Cardoso and Portugal (2005), who study the implications of collective wage bargaining upon wage determination. In order to derive their results, Cardoso and Portugal (2005) assume that bargained wages - basically an industry/occupation specific minimum wage - can be defined as the modal wage for each worker's job category, an assumption that receives support from the sample of jobs for which they collect wage information from collective agreements.

\footnotetext{
${ }^{5}$ Electricity and Gas, and Construction have been included in the Services sector. The agriculture sector also includes Forestry and Fishing.

${ }^{6}$ See also the Appendix for a more detailed analysis of differences in these variables across industries.
} 
Our specific approach underpinning our adoption of the instrument involves arguing first that the greater the SWCW, the lower the average wages paid by the firm. This is straightforward because those contractual wages are wage floors - firms are free to pay above those agreed levels and most workers do indeed earn more). More important, we also argue that the SWCW does not affect directly the level of churning of the firm. In other words, it is not the share of workers that determines their mobility decisions, it is instead the wages themselves. This assumption corresponds to the exclusion restriction.

To sum it up, all the effect from SWCW upon churning in each firm is assumed to take place through the wages paid by the firm; the share is only a predictor, which is also influenced by factors outside the control of the firm, namely the bargaining process that takes place between different employers association and different unions. Moreover, as suggested before, we also expect the relationship between the instrument and wages to be negative: controlling for other variables, the greater the SWCW, the lower the average wage paid by the firm.

Table 3 presents the first set of results. All equations consider all firms (including those with zero churning rates). The first column is based on a tobit model with random effects. We find the expected significantly negative relationship between average pay and churning rates. The following three columns are based on OLS. Column 2 ignores the possible endogeneity of wages across firms while column 3 ignores the possible endogeneity of wage differences within firms, over time. In both cases, we again obtain very significant, negative coefficients of wages. For instance, the result of column 3 indicates that for each $€ 1,000$ extra that each worker earns per month, there is a decline of $1.7 \mathrm{pp}$ in that firm's churning rate. This negative relationship is consistent with the pattern documented in Figure 3, which depicts the level of churning and average pay across all industries in 2004: the fitted line, weighted by industry size, is clearly downward sloping.

However, in column 4, when we instrument wage differences with the shares of workers that are paid collective bargaining wages, we find that the coefficient remains statistically significant, but it is now positive. At 0.32 , the coefficient indicates that there is an increase of $32 \mathrm{pp}$ in a firm's churning rate for each $€ 1,000$ increase of average pay. Although the contribution of the instrument in the first stage is not particularly strong (a partial $\mathrm{R}^{2}$ of 0.0022 ), the instrument is significantly negative, as expected from our discussion above.

Overall, the result suggests that, contrary to previous findings, if firms pay higher wages (because of exogenous reasons), then churning may actually increase. Roughly speaking, a doubling of wages would lead to the doubling of churning.

In order to test the robustness of this (surprising) result, we repeat the analysis of the three last columns of Table 3 but considering only firms-year in which churning is positive (see Table 4). This selection of the sample is motivated by the fact that, as mentioned before, a considerable number of firms does not exhibit churning. In any case, we still find that the same pattern of results emerges, with significantly negative coefficients in the first two specifications (those without instruments) and a positive coefficient (although now insignificant) when wages are instrumented. Finally, we consider the same sample of firms-years (those with positive levels of churning) but now adopting a log-log specification. The same pattern emerges again, with negative elasticities for the first two specifications and an insignificant, but also positive coefficient when wages are instrumented. In both cases, the instruments are significantly negative in the first-stage equations. 


\subsection{Interpretation}

Our finding of a non-negative causal relationship between wages and churning (which is even significantly positive in some specifications) may at first seem counterintuitive. Presumably, if a firm were to increase the wages paid to its workers due to forces outside the firm's control, then workers would be less interested in leaving their jobs. Therefore, churning - understood as "replacement hiring" -, would fall. This would then generate a negative relationship between pay and churning.

In our view, one aspect that may be missing in such analysis concerns the behaviour of firms once their workers become better paid due to exogenous forces. According to some efficiency wage models, wage increases may pay for themselves, but only if workers' effort increase more than proportionately. However, if that were the case, one would presumably expect that firms would be keen to implement those pay rises in the first place, before being forced to do so by virtue of the increase in collective bargaining contractual wages. Moreover, even if firms were not pursuing optimal pay policies, it is still not obvious that collective bargaining wage increases would move them in that direction. Since the outside options of workers earning the minimum wage would necessarily also increase (i.e. the minimum wage in other firms has also increased, due to the collective nature of bargaining), then the incentive for those workers to put in more effort will probably be relatively weak.

Our explanation for the non-negative relationship between wages and churning is therefore that workers' effort may not be sufficiently responsive to wage increases, particularly in the firms most affected by our instrument (a local average treatment effect). Such firms are those that are paying lower wages, so that their wage bill goes up significantly when collective bargaining increases minimum wages. Moreover, if effort does not increase at least in a commensurate way to the increase in pay, then employers may very well prefer to dismiss those workers whose wages exceed their productivity and replace them with more skilled workers. To the extent that not all dimensions of skill are captured in our regression controls, this process of replacement can easily prevent worker churning rates from falling. Such non-decrease of churning will then generate the nonnegative association between wages and churning documented in our study, when using instrumental variables.

Of course, it would be desirable to present additional empirical evidence about this interpretation in future research. One possible way of achieving that would be to follow the individuals whose pay is most affected by collective bargaining (i.e. those workers that earn the industry/occupation minimum wage). One could then examine whether such workers are also more likely to leave their jobs once their wages are increased by virtue of new collective bargaining agreements, as suggested by our interpretation.

\section{Summary}

Our study examined the relationship between churning and wages, using matched data covering the entire population of Portuguese firms between 1986 and 2000. We believe this relationship deserves attention from the points of view of both labour economics and human resource management: While economists may be concerned about the waste of resources that may occur when workers are being constantly replaced in firms, HRM experts may find it helpful to draw on stronger quantitative evidence about how firms may ensure that employer-employee matches are longlasting. 
Given that we are interested in the causal relationship between the two variables, churning and wages, we used within-firm time variation (an improvement upon studies that focus on crosssection variation only). Moreover, we also exploit what we argue is a source of exogenous variation in wages: the share of workers in each firm being paid collective bargaining wages. Using that instrument, we find that the standard negative correlations between wages and churning become a non-negative causal link. We also argue that this finding may be explained by a relatively weak responsiveness of effort to wages in the firms affected by the instrument and the consequent replacement by employers of priced-out workers by more skilled new hires in such a way that churning does not fall.

\section{References}

Abowd, John, Patrick Corbel and Francis Kramarz (1999) "The Entry and Exit of Workers and the Growth of Employment: An Analysis of French Establishments", Review of Economics and $\underline{\text { Statistics, }}$ 81, 170-187.

Akerlof, George and Janet Yellen (1986) Efficiency Wage Models of the Labor Market. Cambridge University Press, Cambridge.

Albaek, Karsten and Bent Sorensen (1998) "Worker Flows and Job Flows in Danish Manufacturing, 1980-91", Economic Journal, 108, 1750-1771.

Bandiera, Oriana, Iwan Barankay and Imran Rasul (2005) "Social Preferences and the Response to Incentives: Evidence from Personnel Data”, Quarterly Journal of Economics, 120, 917-62.

Barth, Erling and Harald Dale-Olsen (1999) "Employer's Wage Policy and Worker Turnover", in J. Haltiwanger, J. Lane, J. Spletzer, J. Theeuwes and K. Troske, editors, "The Creation and Analysis of Linked Employer-Employee Data". Elsevier, North Holland, Amsterdam.

Blanchard, Olivier and Pedro Portugal (2001) "What Hides behind an Unemployment Rate: Comparing Portuguese and U.S. Labor Markets", American Economic Review, 91, 187-207.

Burgess, Simon, Julia Lane and David Stevens (2000) "Job Flows, Worker Flows, and Churning", Journal of Labor Economics, 18, 473-502.

Burgess, Simon, Julia Lane and David Stevens (2001) "Churning Dynamics: An Analysis of Hires and Separations at the Employer Level”, Labour Economics, 8, 1-14.

Dale-Olsen, Harald (2006) "Fringe Attraction. Compensation Policies, Worker Turnover and Establishment Performance”, ISF, mimeo.

Davis, Steven, John Haltiwanger, and Scott Schuh (1996) Job Creation and Destruction. MIT Press, Cambridge, Massachusetts.

Cardoso, Ana Rute and Pedro Portugal (2005) "Contractual Wages and the Wage Cushion under Different Bargaining Settings”, Journal of Labor Economics, 23, 875-902.

Guest, David, Jonathan Michie, Neil Conway and Maura Sheehan (2003) "Human Resource Management and Corporate Performance in the UK", British Journal of Industrial Relations, 41, 291-314. 
Hamermesh, Daniel, Wolter Hassink and Jan van Ours (1996) "Job Turnover and Labor Turnover: A Taxonomy of Employment Dynamics", Annales d'Economie et de Statistique, 41/42, 21-40.

Ilmakunnas, Pekka and Mika Maliranta (2005) "Worker Inflow, Outflow, and Churning", Applied Economics, 37, 1115-1133.

Lane, Julia, David Stevens and Simon Burgess (1996) "Worker and Job Flows", Economics Letters, $51,109-113$.

Lazear, Edward (1995) Personnel Economics. MIT Press, Cambridge, Massachusetts.

Martins, Pedro (2006a) "Inter-Firm Worker Mobility: Some Stylised Facts", Queen Mary, University of London, mimeo.

Martins, Pedro (2006b) "Worker Churning and Within-Firm Job Flows”, Queen Mary, University of London, mimeo.

Varejão, José (2003) "Job and Worker Flows in High Adjustment Cost Settings", Portuguese Economic Journal, 2, 37-51. 


\section{Tables and Figures}

Table 1 - Descriptive Statistics

\begin{tabular}{lcccccc} 
& \multicolumn{2}{c}{ All Firms } & \multicolumn{2}{c}{1987} & \multicolumn{2}{c}{2000} \\
Variable & Mean & Std. Dev & Mean & Std. Dev & Mean & Std. Dev \\
Firm Size & $1,032.0$ & 3521.0 & $1,715.5$ & $5,155.3$ & 688.5 & $2,285.8$ \\
First Year & 0.03 & 0.18 & 0.04 & 0.19 & 0.04 & 0.19 \\
Last Year & 0.05 & 0.21 & 0.04 & 0.19 & 0.00 & 0.00 \\
Foreign Firm & 0.09 & 0.29 & 0.09 & 0.28 & 0.11 & 0.31 \\
Female & 0.39 & 0.31 & 0.34 & 0.29 & 0.42 & 0.32 \\
Schooling & 6.70 & 2.38 & 5.81 & 1.92 & 7.57 & 2.64 \\
Experience & 24.08 & 7.03 & 24.99 & 6.44 & 23.55 & 7.43 \\
Tenure & 99.65 & 71.20 & 111.24 & 66.57 & 89.46 & 69.32 \\
Months since Last & & & & & & \\
Promotion & 56.30 & 49.19 & 56.34 & 41.19 & 58.22 & 50.18 \\
Job Creation Rate & 0.14 & 0.37 & 0.13 & 0.38 & 0.15 & 0.39 \\
Job Destruction Rate & 0.12 & 0.34 & 0.09 & 0.31 & 0.18 & 0.49 \\
Net Job Creation Rate & 0.02 & 0.54 & 0.04 & 0.51 & -0.03 & 0.67 \\
Hiring Rate & 0.23 & 0.40 & 0.21 & 0.40 & 0.26 & 0.41 \\
Separation Rate & 0.22 & 0.36 & 0.17 & 0.32 & 0.27 & 0.44 \\
Worker Reallocation Rate & 0.46 & 0.52 & 0.38 & 0.49 & 0.52 & 0.57 \\
Monthly Pay & 738.22 & 446.55 & 595.45 & 309.45 & 813.95 & 490.96 \\
Hourly Pay & 4.54 & 3.40 & 3.56 & 2.14 & 5.10 & 3.29 \\
Binding Wages & 0.18 & 0.23 & 0.19 & 0.21 & 0.18 & 0.25
\end{tabular}

Notes: Author's calculations based on "Quadros de Pessoal" data. "Firm size" refers to the number of workers in each firm; "first year" and "last year" are dummy variables taking value one when the firm appears for the first or last time in the data, respectively; "foreign firm" is a dummy variable taking value one if at least $50 \%$ of the equity of the firm is held by foreign investors; "schooling" refers to the years of schooling attained by each worker; "tenure" is measured in months; "monthly" and "hourly pay" are measured in 2004 euros; "binding wages" refer to the percentage of the workforce in each firm that is paid the wage determined by collective bargaining (this is measured adapting the approach of Cardoso and Portugal, 2005), considering only the worker's occupation or his/her occupation and industry (see main text for more details). Job and worker flow rates follow the standard definition in the literature (more details in the main text). 
Table 2 - Job and Worker Flows Rates, 1986-2000, by Sector

\begin{tabular}{|c|c|c|c|c|c|}
\hline Sector & $\begin{array}{c}\text { Job } \\
\text { Creation }\end{array}$ & $\begin{array}{c}\text { Job } \\
\text { Destruction }\end{array}$ & $\begin{array}{l}\text { Net Job } \\
\text { Creation }\end{array}$ & $\begin{array}{c}\text { Job } \\
\text { Reallocation }\end{array}$ & \\
\hline Agriculture & 0.198 & 0.194 & 0.005 & 0.392 & \\
\hline Manufacturing & 0.109 & 0.113 & -0.004 & 0.222 & \\
\hline Services & 0.166 & 0.123 & 0.044 & 0.289 & \\
\hline Sector & Hiring & Separation & $\begin{array}{c}\text { Worker } \\
\text { Reallocation }\end{array}$ & $\begin{array}{l}\text { Worker } \\
\text { Churning }\end{array}$ & $\begin{array}{l}\text { W. Churning I } \\
\text { W. Reallocation }\end{array}$ \\
\hline Agriculture & 0.340 & 0.351 & 0.691 & 0.265 & 0.439 \\
\hline Manufacturing & 0.188 & 0.203 & 0.392 & 0.163 & 0.518 \\
\hline Services & 0.275 & 0.241 & 0.515 & 0.218 & 0.502 \\
\hline
\end{tabular}

Notes: Job and worker flow rates follow the standard definition in the literature (more details in the main text). 
Table 3 - Impact of Wages on Churning (All Firms)

Dependent variable: Churning Rate; Years used: 1987-2000, except 1990

1

Avg pay

$\begin{array}{ll}-0.029^{\star \star *} & -.076^{\star \star *} \\ {[0.000]} & {[0.000]}\end{array}$

Fixed Effects

IV

R-squared

No. obs

2
Notes: Column 1 is based on a random effects tobit model. Column 2 is based on pooled OLS. The coefficient of the instrumental variable in the first-stage equation is -.067 (t-ratio: -9.44), with a partial R2 of 0.0022 and an F-statistic of 89.05. Controls used in all regressions: year dummies, percentage of women, average education, average experience, sales, equity and log firm size. The explanatory variable is measured in thousands of euros(2004 prices). Only firms present three or more years over 1987-2000 are included in the analysis. Robust standard errors. ${ }^{*} p<0.05,{ }^{* \star} p<0.01,{ }^{* \star *}$ $\mathrm{p}<0.001$.
3

$-.017^{\star * *}$

[0.000]

$\mathrm{X}$

$x$

4

$.320 * \star \star$

[0.000]

$0.571 \quad-0.022$

$931093 \quad 931093$

$\begin{array}{rrr}0.119 & 0.571 & -0.022 \\ 931093 & 931093 & 931093\end{array}$


Table 4 - Impact of Wages on Churning (Only Firms with Positive Levels of Churning)

Dependent variable: Churning Rate or Log Churning Rate; Years used: 1987-2000, except 1990

1

Dependent

Variable

Avg pay

Log avg pay

$\begin{array}{ll}-0.106^{\star \star \star} & -0.025^{\star \star \star} \\ {[0.006]} & {[0.005]}\end{array}$

$[0.006] \quad[0.005]$

Log avg pay

Fixed Effects

IV

R-squared

No. obs
2

Churning Rate

3 $\begin{array}{lll}4 & 5 & 6\end{array}$

\author{
Log Churning Rate
}

Notes: The coefficient of the instrumental variable in the first-stage equation of column 3 is -.064 (t-ratio: -5.59), with a partial R2 of 0.0017 and an F-statistic of 31.26. For column 6 , the instrumental variable in the first-stage equation coefficient is -.055 (t-ratio: -6.72 ), with a partial R2 of 0.0016 and an F-statistic of 45.09 . Controls used in all regressions: year dummies, percentage of women, average education, average experience, sales, equity and log firm size. The explanatory variable is measured in thousands of euros (2004 prices). Only firms present three or more years over 19872000 are included in the analysis. Robust standard errors. * $p<0.05,{ }^{\star *} p<0.01,{ }^{\star * *} p<0.001$ 
Figure 1 - Distribution of Net Job Creation Rates, 2000, All Firms

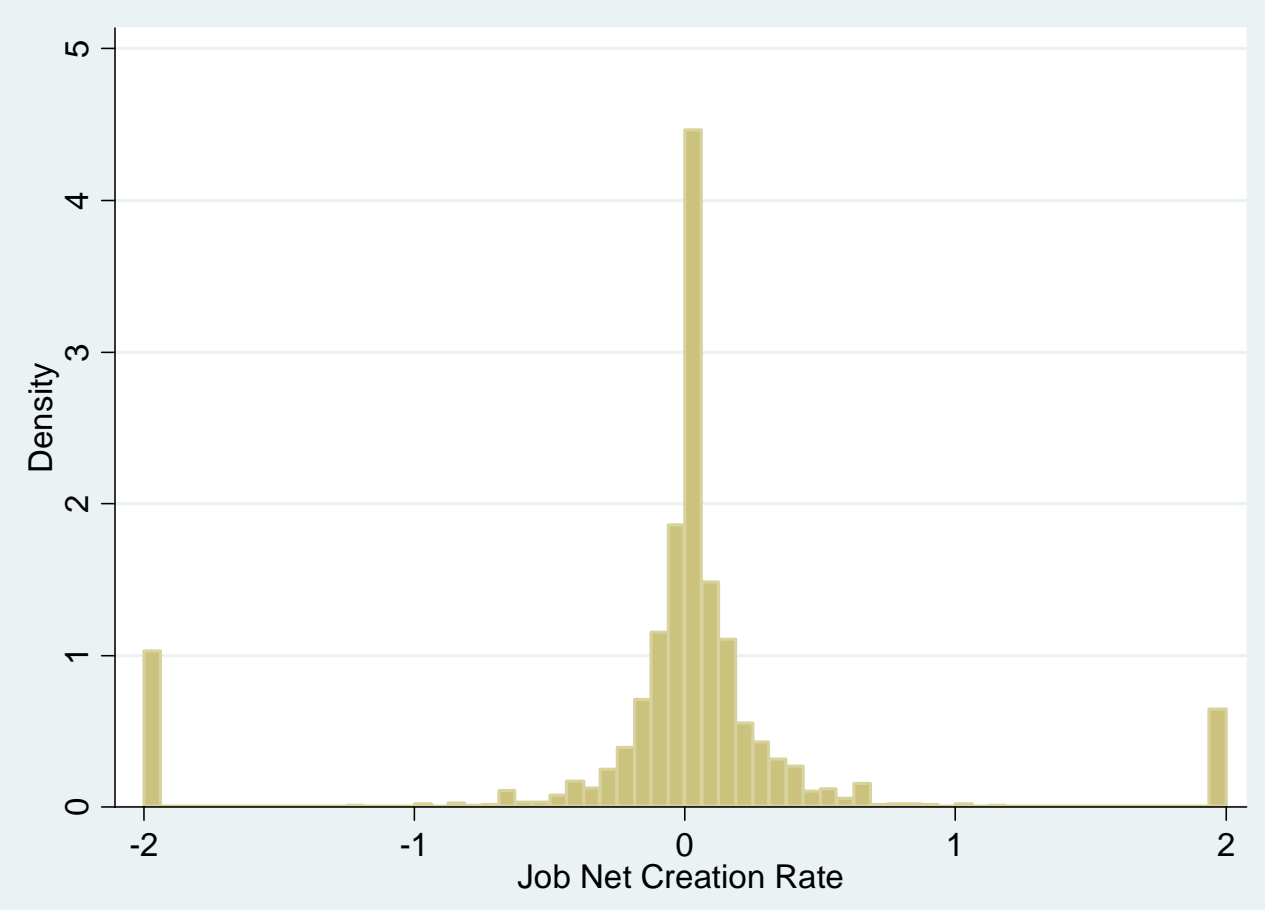

Source: Author's calculation based on "Quadros de Pessoal” data. 
Figure 2 - Distribution of Churning Rates, 2000, All Firms

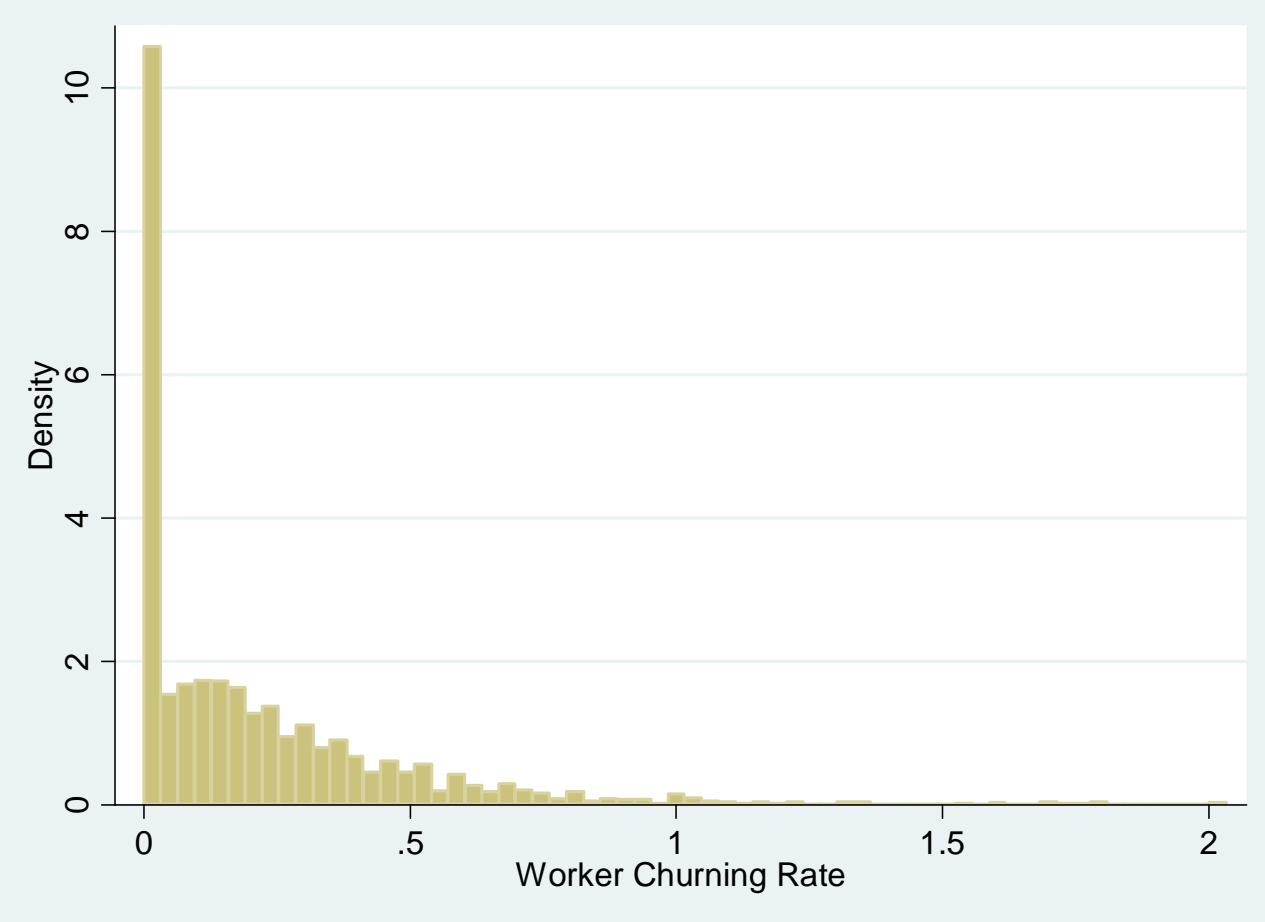

Source: Author's calculation based on "Quadros de Pessoal" data. 
Figure 3 - Churning Rates and Average Pay per Industry, 2000

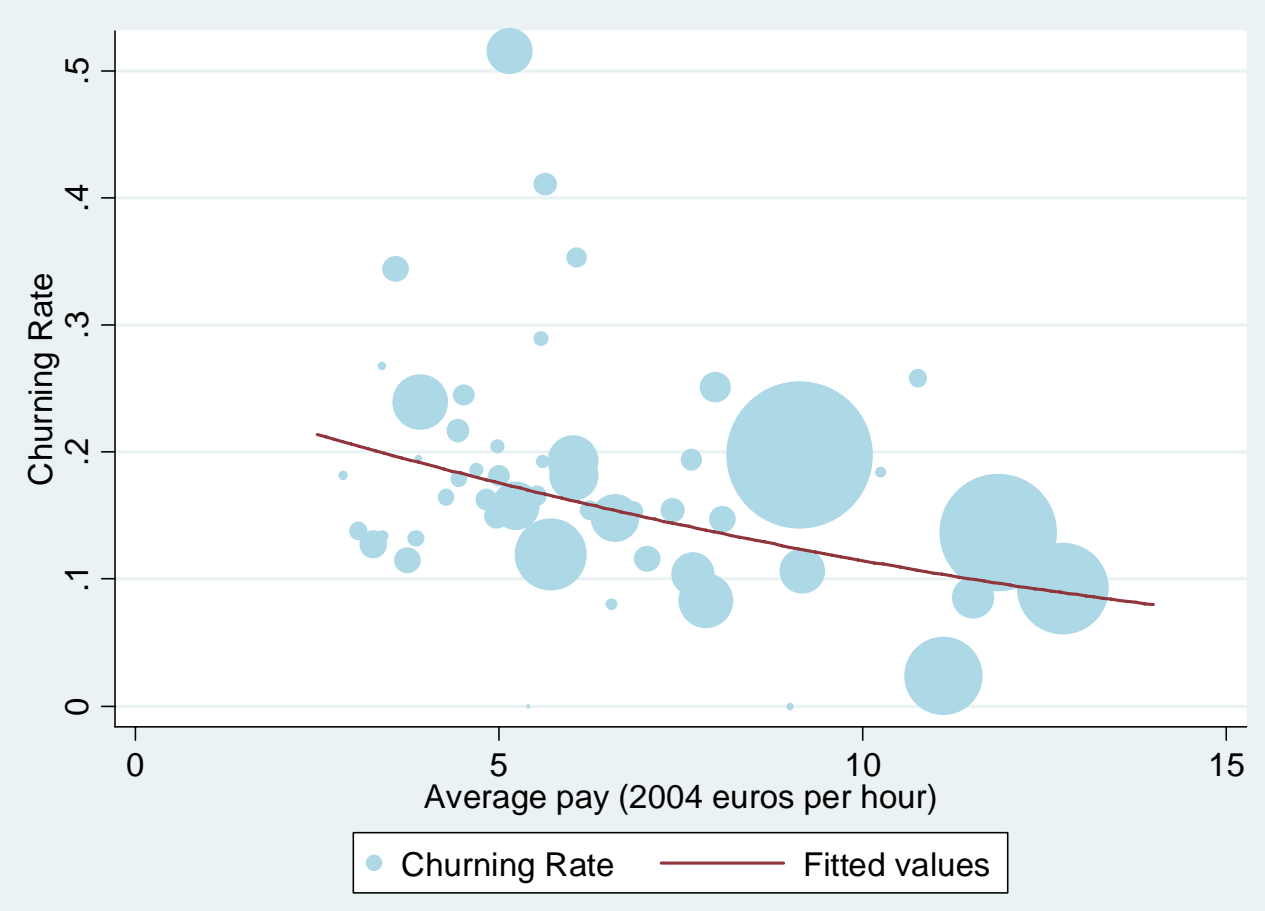

Source: Author's calculation based on "Quadros de Pessoal" data.

Note: The size of each industry in the Figure is proportional to its size, as measured in terms of employment. 


\section{Appendix}

Table A1 decomposes information about job and worker flows and churning rates into two-digit industries for all three sectors. The results below support the findings of considerable heterogeneity in job flows, an important result of Davis et al (1996). For instance, while net job creation rates in manufacturing are negative over the 1986-2000 period (although at only $-0.4 \%$ ), specific industries can exhibit very different patterns.

On the one extreme, firms in the 'Petroleum and Natural Gas' industry have employment declines of $103 \%$, and those in 'Coke and Refined Petroleum' see their number of jobs falling by $12.2 \%$; on the other extreme, the 'Recycling' and 'Motor Vehicles' industries increase their jobs by $10.5 \%$ and $3.2 \%$. Moreover, job reallocation rates also tend to be high although, again, they vary considerably across industries. These results are further evidence of the dynamic nature of labour markets and the constant reshuffling of jobs across firms, within or not the same industries.

Table A1 - Job and Worker Flows Rates, 1986-2000, by Industry

Industry
Agriculture
Forestry
Fishing
Mining
Petroleum and Natural Gas
Mining of Uranium
Mining of Metal Ores
Other Mining and Quarrying
Food Products and Beverages
Tobacco Products
Textiles
Wearing Apparel
Leather, Luggage, and Footwear
Wood and Products of Wood and Cork
Paper and Paper Products
Publishing, Printing
Coke, Refined Petroleum
Chemicals
Rubber and Plastics Products
Other Non-Metallic Mineral Products
Basic Metals
Fabricated Metal Products
Machinery and Equipment
Office, Accounting and Computing Machine
Electrical Machinery
Radio, Television, Communication Equipme
Medical, Precision, Optical Instruments
Motor Vehicles
other Transport Equipment
Furniture
Recycling
Electricity, Gas
Water
Construction
Sale, Maintenance of Vehicles; Fuel
Poding

\begin{tabular}{cccc}
$\begin{array}{c}\text { Job } \\
\text { Creation }\end{array}$ & $\begin{array}{c}\text { Job } \\
\text { Destruction }\end{array}$ & $\begin{array}{c}\text { Net Job } \\
\text { Creation }\end{array}$ & $\begin{array}{c}\text { Job } \\
\text { Reallocation }\end{array}$ \\
0.204 & 0.194 & 0.010 & 0.398 \\
0.244 & 0.208 & 0.036 & 0.452 \\
0.124 & 0.181 & -0.057 & 0.306 \\
0.015 & 1.529 & -1.513 & 1.544 \\
0.000 & 1.029 & -1.029 & 1.029 \\
0.082 & 0.054 & 0.029 & 0.136 \\
0.062 & 0.153 & -0.091 & 0.215 \\
0.142 & 0.118 & 0.025 & 0.260 \\
0.098 & 0.112 & -0.014 & 0.210 \\
0.029 & 0.066 & -0.038 & 0.095 \\
0.070 & 0.106 & -0.036 & 0.176 \\
0.144 & 0.127 & 0.017 & 0.271 \\
0.120 & 0.109 & 0.011 & 0.228 \\
0.122 & 0.133 & -0.011 & 0.255 \\
0.070 & 0.104 & -0.034 & 0.173 \\
0.112 & 0.097 & 0.015 & 0.209 \\
0.003 & 0.125 & -0.122 & 0.129 \\
0.072 & 0.115 & -0.043 & 0.186 \\
0.101 & 0.100 & 0.001 & 0.201 \\
0.103 & 0.101 & 0.002 & 0.204 \\
0.072 & 0.129 & -0.058 & 0.201 \\
0.136 & 0.119 & 0.017 & 0.255 \\
0.103 & 0.105 & -0.002 & 0.208 \\
0.215 & 0.215 & 0.000 & 0.430 \\
0.132 & 0.102 & 0.029 & 0.234 \\
0.134 & 0.136 & -0.002 & 0.270 \\
0.080 & 0.079 & 0.001 & 0.159 \\
0.121 & 0.090 & 0.032 & 0.211 \\
0.081 & 0.125 & -0.044 & 0.206 \\
0.126 & 0.115 & 0.012 & 0.241 \\
0.217 & 0.112 & 0.105 & 0.329 \\
0.091 & 0.128 & -0.037 & 0.219 \\
0.039 & 0.042 & -0.002 & 0.081 \\
0.202 & 0.152 & 0.049 & 0.354 \\
0.141 & 0.111 & 0.030 & 0.252 \\
& & & \\
\hline
\end{tabular}




$\begin{array}{lllll}\text { Wholesale Trade } & 0.152 & 0.120 & 0.031 & 0.272 \\ \text { Retail Trade } & 0.194 & 0.136 & 0.058 & 0.329 \\ \text { Hotels and Restaurants } & 0.192 & 0.141 & 0.050 & 0.333 \\ \text { Land Transport } & 0.103 & 0.092 & 0.011 & 0.194 \\ \text { Water Transport } & 0.089 & 0.133 & -0.044 & 0.222 \\ \text { Air Transport } & 0.042 & 0.030 & 0.013 & 0.072 \\ \text { Auxiliary Transport; Travel Agencies } & 0.125 & 0.117 & 0.008 & 0.242 \\ \text { Post and Telecommunications } & 0.110 & 0.120 & -0.010 & 0.230 \\ \text { Financial Intermediation } & 0.059 & 0.062 & -0.003 & 0.121 \\ \text { Insurance and Pension Funding } & 0.075 & 0.083 & -0.009 & 0.158 \\ \text { Activities auxiliary to Finance } & 0.215 & 0.117 & 0.097 & 0.332 \\ \text { Real Estate } & 0.284 & 0.176 & 0.108 & 0.460 \\ \text { Renting of Machinery and Equipment } & 0.185 & 0.112 & 0.074 & 0.297 \\ \text { Computer and related activities } & 0.294 & 0.127 & 0.167 & 0.421 \\ \text { Research and Development } & 0.178 & 0.110 & 0.068 & 0.287 \\ \text { Other Business activities } & 0.241 & 0.134 & 0.107 & 0.374 \\ \text { Public Administration and Defence } & 0.156 & 0.098 & 0.058 & 0.255 \\ \text { Education } & 0.139 & 0.088 & 0.051 & 0.227 \\ \text { Health and Social Work } & 0.144 & 0.074 & 0.069 & 0.218 \\ \text { Sewage and Refuse Disposal, Sanitation } & 0.343 & 0.067 & 0.275 & 0.410 \\ \text { Activities of Membership Organizations } & 0.119 & 0.109 & 0.010 & 0.227 \\ \text { Recreational and Sporting activities } & 0.128 & 0.100 & 0.028 & 0.227 \\ \text { Other Service activities } & 0.210 & 0.160 & 0.050 & 0.370 \\ \text { Extra-Territorial Organizations } & 0.146 & 0.149 & -0.002 & 0.295\end{array}$

Table A2 presents worker flows across all two-digit industries, over the 1986-2000 period. A striking result from this table is the considerable dispersion of worker reallocation rates across industries. They range between $171 \%$ and $162 \%$ for 'Petroleum and Natural Gas' and 'Mining' to as little as $13.1 \%$ and $16.9 \%$ in 'Water' and 'Financial Intermediation', respectively.

Churning rates also vary considerably across industries. They range from $0 \%$ and $3.1 \%$ in 'Petroleum and Natural Gas' and 'Mining' to as much as $43.1 \%$ and $39.5 \%$ in 'Fishing' and 'Other Business Activities' (which includes, for instance, 'Cleaning Services' firms), respectively. However, as suggested before, in the comparison between the manufacturing and the services sectors, there is much less dispersion across industries in the ratios between churning and worker reallocation rates (the coefficient of variation drops to about half), indicating that the two rates are positively correlated (an unweighted Pearson correlation of 18\%).

Table A2 - Worker Flows Rates, 1986-2000, by Industry

$\begin{array}{lccccc} & \text { Hiring } & \text { Separation } & \begin{array}{c}\text { Worker } \\ \text { Realloc. }\end{array} & \begin{array}{c}\text { Worker } \\ \text { Churning }\end{array} & \begin{array}{c}\text { W.Churn. I } \\ \text { W.Realloc. }\end{array} \\ \text { Agriculture } & 0.338 & 0.342 & 0.680 & 0.247 & 0.423 \\ \text { Forestry } & 0.366 & 0.339 & 0.705 & 0.218 & 0.336 \\ \text { Fishing } & 0.340 & 0.421 & 0.761 & 0.431 & 0.609 \\ \text { Mining } & 0.032 & 1.592 & 1.624 & 0.031 & 0.036 \\ \text { Petroleum and Natural Gas } & 0.000 & 1.714 & 1.714 & 0.000 & 0.000 \\ \text { Mining of Uranium } & 0.076 & 0.114 & 0.190 & 0.054 & 0.071 \\ \text { Mining of Metal Ores } & 0.117 & 0.211 & 0.328 & 0.115 & 0.539 \\ \text { Other Mining and Quarrying } & 0.247 & 0.236 & 0.483 & 0.216 & 0.484 \\ \text { Food Products and Beverages } & 0.199 & 0.227 & 0.426 & 0.213 & 0.579 \\ \text { Tobacco Products } & 0.083 & 0.120 & 0.202 & 0.108 & 0.507 \\ \text { Textiles } & 0.126 & 0.171 & 0.297 & 0.119 & 0.512\end{array}$




\begin{tabular}{|c|c|c|c|c|c|}
\hline Wearing Apparel & 0.233 & 0.222 & 0.455 & 0.168 & 0.526 \\
\hline Leather, Luggage, and Footwear & 0.207 & 0.204 & 0.411 & 0.172 & 0.556 \\
\hline Wood and Products of Wood and Cork & 0.204 & 0.226 & 0.430 & 0.164 & 0.478 \\
\hline Paper and Paper Products & 0.126 & 0.171 & 0.297 & 0.121 & 0.517 \\
\hline Publishing, Printing & 0.195 & 0.191 & 0.386 & 0.172 & 0.529 \\
\hline Coke, Refined Petroleum & 0.024 & 0.149 & 0.173 & 0.040 & 0.400 \\
\hline Chemicals & 0.122 & 0.183 & 0.305 & 0.119 & 0.475 \\
\hline Rubber and Plastics Products & 0.187 & 0.196 & 0.382 & 0.176 & 0.548 \\
\hline Other Non-Metallic Mineral Products & 0.188 & 0.196 & 0.384 & 0.177 & 0.545 \\
\hline Basic Metals & 0.130 & 0.196 & 0.326 & 0.120 & 0.437 \\
\hline Fabricated Metal Products & 0.234 & 0.224 & 0.458 & 0.194 & 0.507 \\
\hline Machinery and Equipment & 0.184 & 0.194 & 0.377 & 0.168 & 0.515 \\
\hline Office, Accounting \& Computing Machines & 0.276 & 0.288 & 0.564 & 0.113 & 0.339 \\
\hline Electrical Machinery & 0.222 & 0.210 & 0.432 & 0.193 & 0.509 \\
\hline Radio, Television, Communication Equip. & 0.187 & 0.223 & 0.409 & 0.123 & 0.421 \\
\hline Medical, Precision, Optical Instruments & 0.146 & 0.148 & 0.294 & 0.135 & 0.553 \\
\hline Motor Vehicles & 0.181 & 0.169 & 0.350 & 0.143 & 0.510 \\
\hline other Transport Equipment & 0.131 & 0.181 & 0.312 & 0.102 & 0.407 \\
\hline Furniture & 0.215 & 0.209 & 0.424 & 0.163 & 0.481 \\
\hline Recycling & 0.308 & 0.212 & 0.519 & 0.181 & 0.459 \\
\hline Electricity, Gas & 0.129 & 0.100 & 0.229 & 0.031 & 0.370 \\
\hline Water & 0.062 & 0.068 & 0.131 & 0.054 & 0.535 \\
\hline Construction & 0.358 & 0.313 & 0.671 & 0.301 & 0.517 \\
\hline Sale, Maintenance of Vehicles; Fuel & 0.231 & 0.211 & 0.442 & 0.178 & 0.496 \\
\hline Wholesale Trade & 0.242 & 0.225 & 0.467 & 0.189 & 0.496 \\
\hline Retail Trade & 0.291 & 0.248 & 0.539 & 0.194 & 0.432 \\
\hline Hotels and Restaurants & 0.359 & 0.312 & 0.671 & 0.318 & 0.552 \\
\hline Land Transport & 0.153 & 0.156 & 0.309 & 0.119 & 0.507 \\
\hline Water Transport & 0.189 & 0.249 & 0.438 & 0.211 & 0.599 \\
\hline Air Transport & 0.101 & 0.097 & 0.198 & 0.127 & 0.693 \\
\hline Auxiliary Transport; Travel Agencies & 0.187 & 0.196 & 0.383 & 0.143 & 0.314 \\
\hline Post and Telecommunications & 0.159 & 0.171 & 0.330 & 0.100 & 0.594 \\
\hline Financial Intermediation & 0.075 & 0.094 & 0.169 & 0.064 & 0.518 \\
\hline Insurance and Pension Funding & 0.085 & 0.127 & 0.213 & 0.074 & 0.395 \\
\hline Activities auxiliary to Finance & 0.289 & 0.202 & 0.491 & 0.137 & 0.317 \\
\hline Real Estate & 0.399 & 0.286 & 0.685 & 0.193 & 0.372 \\
\hline Renting of Machinery and Equipment & 0.317 & 0.254 & 0.571 & 0.259 & 0.514 \\
\hline Computer and related activities & 0.412 & 0.247 & 0.659 & 0.222 & 0.425 \\
\hline Research and Development & 0.284 & 0.231 & 0.516 & 0.224 & 0.527 \\
\hline Other Business activities & 0.440 & 0.348 & 0.788 & 0.395 & 0.543 \\
\hline Public Administration and Defence & 0.255 & 0.199 & 0.455 & 0.171 & 0.522 \\
\hline Education & 0.233 & 0.195 & 0.429 & 0.196 & 0.548 \\
\hline Health and Social Work & 0.216 & 0.154 & 0.370 & 0.148 & 0.512 \\
\hline Sewage and Refuse Disposal, Sanitation & 0.504 & 0.224 & 0.728 & 0.302 & 0.497 \\
\hline Activities of Membership Organizations & 0.171 & 0.180 & 0.351 & 0.121 & 0.395 \\
\hline Recreational and Sporting activities & 0.226 & 0.212 & 0.438 & 0.205 & 0.551 \\
\hline Other Service activities & 0.318 & 0.268 & 0.586 & 0.181 & 0.374 \\
\hline Extra-Territorial Organizations & 0.202 & 0.193 & 0.395 & 0.068 & 0.308 \\
\hline
\end{tabular}

This relationship between churning and worker reallocation rates can also be inferred from Figure A1, which plots job and worker reallocation rates by industry in 2000. Since churning is the difference between the two, the Figure suggests that churning increases with worker reallocation. 
Figure A1 - Job Reallocation and Worker Reallocation, by Industry, 2000

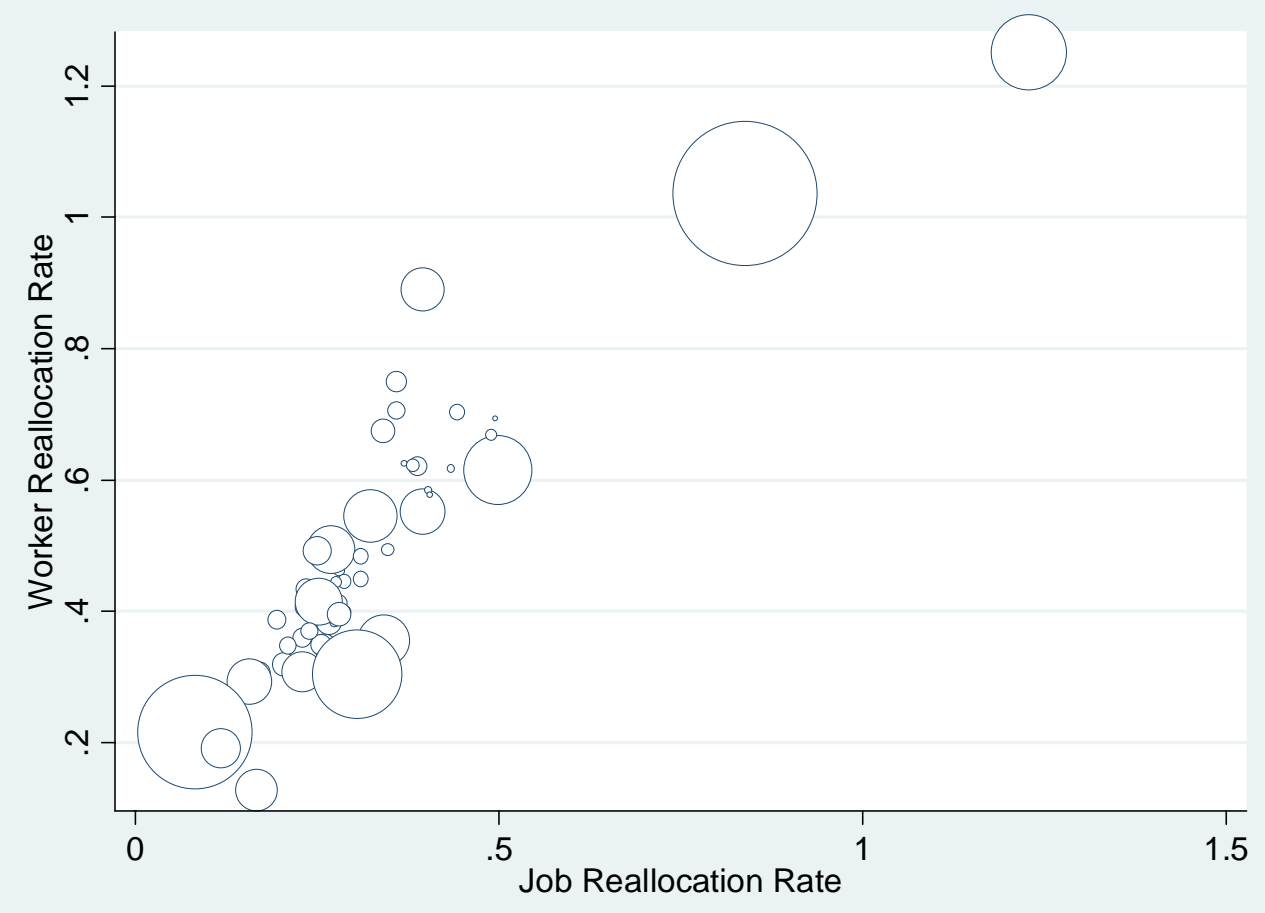

